\title{
Investigation of Obstacles and Strategies of Rural Tourism Development Using SWOT Matrix
}

\author{
Beytola Mahmoudi \\ MSc graduated of Natural Resource \\ Tel: 98-937950-2391_E-mail: baytoo_m@yahoo.com \\ Amin Haghsetan (Corresponding author) \\ MSc graduated of forestry, Department of forestry, University of Tehran, Iran \\ PO box 31585-3314, Karaj, Iran \\ Tel: 98-917842-0295Ｅ-mail: haghsetan@gmail.com \\ Raheleh Maleki \\ Student of tourism management (MSc) \\ PO box 19367-85551, Tehran, Iran \\ Tel: 98-912298-9598Ｅ-mail: Raheleh878@gmail.com
}

Received: December 1, 2010

Accepted: January 5, 2011

doi:10.5539/jsd.v4n2p136

\begin{abstract}
Decrease in rural area's population and increase in the urbanity rate in recent years is a result of poverty and the absence of proper access to resources of welfare and livelihood services. Optimum usages of environmental, economical and production potentials of rural areas for improving income and welfare can be efficient in reaching the goal of reducing the rural immigration. Rural tourism is a part of tourism market and is a source of employment and income. Also it can be presented as a significant tool for the socio-economical development of rural areas. To recognize the guidelines in this study for tourism development in Kore Shahbazi and Tassouj as target tourism villages in Kohgiloye and BouyrAhmad province of Iran, the internal factors assessment (Strengths \& weaknesses) and external factors (opportunities \& threats) and SWOT matrix were used. In this study, bioenvironmental; tourism; economical; socio-cultural; and legal-political factors were used in performed analyzing. According to this consideration, six tourism development strategies were determined for each village. Protection of village recreational attractions(ST strategy), developing infrastructure for tourism and introducing village recreational attractions to attract tourist (WO strategy) nature, historic and religious tourism planning (SO strategy) and planning for attraction-based tourism (WT strategy) were determined as tourism development strategies in target villages. Also, developing flora, bio-environmental management of natural resources, infrastructure development, increase in employment capacity, immigration control and native cooperation development in planning were determined as rural development strategies which play an important role in implementation of the tourism development strategy in the area.
\end{abstract}

Keywords: Rural development, Development strategy, Tourism target villages, Kohgilouye County

\section{Introduction}

Today, Villages are one of the resources, attracting the attention of tourism planners more than ever. Those with some specific cultural, natural or social appeal have a very strong potential for attracting tourists from close or remote areas and this can have significant role in rural development (Mostowfi, 2000). Rural development is a strategy for improving economical and social life of poor villagers and a multilateral endeavor to reduce the poverty. That will especially be possible through increase in production and promote productivity in rural environment (Yadghar, 2004). Rural tourism in one of the forms of sustainable development that through promoting productivity in rural zones, brings about employment, income distribution, preservation of village environment and local culture, raising host community's participation and presenting appreciate methods to conform beliefs and traditional values with new circumstances. This will bring lots of benefits to rural zones 
(Kanaani, 2005). In reality, rural tourism will cause the development of social and economical aspects of a village in long terms. It can be said that one of the operational strategies for the development of rural areas is the implementation of village tourism program in potential areas. Rural tourism provides new motivations to go on cultural, social and economical activities by presenting new economic opportunities (Sharpley, 2001). In fact, proper rural tourism program not only makes these activities performed by a greater motivation, but also provides new sources of income for the villagers. Rural tourism planning process begins with choosing qualified villages to attract tourists. In fact the first step of rural tourism planning management is to select potential villages for rural tourism. Finally the managerial operations must be implemented in order to maximize the benefits of rural tourism processes. In our country, potential villages for tourism were determined as target villages for tourism in different provinces; but the mentioned steps for planning and management in rural tourism were performed for just a few villages, the reason being too many management and infrastructure difficulties as the obstacles. We have investigated the obstacles and ways for rural development, describing the bio-environmental properties of two target villages in tourism of Kohgilouye County.

\section{Study area and the consideration method}

Target villages for tourism under study are Cheshmeh Belgheis and Tassoj villages which are located in Kohgilouye and Boyer Ahmad province, Iran. Dehdasht city is the centre of Kohgilouye County. Kore Shahbazi cheshme village of Cheram with $50^{\circ} 44^{\prime}$ east longitude and 30 $0^{\circ} 43^{\prime}$ north latitude is located in $5 \mathrm{~km}$ south east from Cheram city and $23 \mathrm{~km}$ from Dehdasht. Also, Tassouj village with $51^{\circ} 5^{\prime}$ fast longitude and $30^{\circ} 40^{\prime}$ latitude is located in $80 \mathrm{~km}$ east north of Cheram city and $160 \mathrm{~km}$ of Yasouj city. To analyze the bio-environmental properties and particularly social and economical position of two mentioned villages to recognize the capabilities and limitation for rural developments, the external and internal assessment affecting the development process were used. Also external and internal factors analysis with SWOT matrix were used to extract the development strategies (Aarabi, 2006, Fred, 1999). For this aim, the properties of two villages were described, then external and internal factors were assessed and finally with illustrating SWOT matrix, the tourism development strategies in the area were proposed.

\section{Environmental, Social and Tourism Properties of Tourism Target Villages in the County}

\subsection{Kore Shahbazi Village}

This village has an altitude of $705 \mathrm{~m}$ from the sea. Its climate in the spring and autumn is mild and pleasant; it is hot in summer and it is fairly cold in winter. Taghar river crosses from the west of the village. This village is limited to Garbajouli Mountain from west. It has a population of 1053, based on the 1996 publict census (National statistical Center of Iran, 2006) and increased to 2186 in the year 2006 (National statistical Center of Iran, 2006).The date of residential forming of Cheshme Belgheis is related to modern periods. The garden of Cheshme Belgheis, historical castle of Tall-e-Baboune and Fashian Castle, tell us about historic precedence of this village. It was the countryside for Ghashgai tribe. Its people speak in Lori language. Some of its people were from nomadic tribes. They decamp from second half of May to countryside and stay there until September. It is accessible through Cheram, Dehdasht and Dogonbadan by asphalt road. Kore Shahbazi village taking advantage of appropriate ecological conditions, beautiful perspectives, green gardens and healthy weather has many potentials to attract tourists and nature-lovers. The main tourism attraction of the village is the garden of Cheshme Belgheis with more than 100 years of history, now a beautiful park. Some of the significant properties of the garden of Cheshme Belghies are native non-native trees that belong to different ecologies. The garden irrigation is done using Cheshme Belghies water. Netted rivulets with special architecture were designed that finally reach into a beautiful pool. This garden which is full of tree has a very nice view and is worth seeing. One historic attraction of this village to be mentioned here is the historic castle of Tall-e-Baboune in $2 \mathrm{~km}$ distanse from the village and Fashian Castle in the village neighborhood.

\subsection{Tassouj Village}

The weather in Tassouj' is mild in spring and summer and too cold in winter. It has an altitude of $2020 \mathrm{~m}$ from the sea. There, remained some petrography from the Qajar dynasty in Tassouj village. Based on public census of 1996 (National statistical Center of Iran, 1996), this village had a population of 250 that increased to 380 in the years 2006 (National statistical Center of Iran, 2006). The economy of the village is based on agriculture, animal husbandry, gardening operations and other service jobs. Agiculture has a long precedent in this village, too. Tassouj village is accessible through Dehdasht and Cheram cities by dirt road. Verdant nature, mild weather, nice view of springs, rivers, waterfalls, forests and wild life around the village, attract lots of tourists in different times to Tassouj village. Tassouj's waterfall has a very nice crown and bed. Pleasant and thriving place for recreation around the waterfall with various springs in spring and summer is worth seeing. Existing stone tomb 
in heights adjacent to the village and petrography relevant to Qajar dynasty are among other natural and historic attractions of this village. Also Golbahar Shrine in the center of the village, has so many pilgrims in different times of year.

\section{External and Internal Factors Assessment}

To assess the internal and external factors affecting the development process of target villages for tourism, first the index of these factors must be determined. Most important factors include bio-environmental, tourism, economical, social-cultural and legal-political factors. Strengths and weaknesses (internal factors) and opportunity and threat (external factors) for those villages are listed in tables 1, 2 .

\section{Determination of the Operational Strategies}

Planning for rural development should be based on development capabilities and advantages of each village so as to form the development plan of each village based on its potentials. Hence, regarding the fact that planning capability for rural development of these two villages is tourism, its development plan should be based on tourism. Regarding the close relation of tourism development and bio-environmental, economical, socio-cultural, and legal-political factors, it is necessary to consider the capabilities and limitations of these factors. So development strategies and operational ways about these factors were determined and are shown in tables 3 and 4. For the aim of determining the appropriate strategies, and because the aim has been the removal of the limitations to implement the tourism programs, the basis for this decision-making has been the weaknesses and the threats concerning the study area.

\section{Strategies for Tourism Development}

As mentioned earlier, tourism development is the main pivot for rural development in two villages. So, development strategies for rural tourism in these two villages are listed in tables 5 and 6 based on external and internal factors in SWOT matrices. Six key strategies determined for each village according to these tables.

\section{Discussion and Results}

Kohgilouye and Boyer Ahmad province in general is of the most deprived provinces in the country, the distance from the capital and hardness of accessibility being the reasons for its slow development. The lowest rate of growth is in this province and most of its population resides in rural zones. Having lots of villages most of which do not show traces of modern cities presents a good opportunity for the implementation of rural development patterns. As mentioned before, rural tourism development is one of the rural development approaches conforming to the principles of sustainability. The most important factors to plan for tourism are attractions and recreation resources in rural environment. Most of rural tourism attractions are natural attractions. Kohgilouye and Bouyer Ahmad province is in the first rank in having forest measurement ratio to total measurement of province, 997100 hectares of forests. Protecting cultural, social and native genuineness in the villages of the province and also the presence of less-ruined natural resources had presented a very good opportunity to plan for rural tourism in this province. In this study, affecting factors on the process to analyze the tourism planning in target villages of Kohgilouye County were considered. To obtain strategies and operational ways, bio-environmental, economical, social-cultural, legal-political factors were considered as tools to execute tourism development programs in target villages. It means that for the successful sustainable execution of rural tourism development, it is essential to analyze affecting factors on tourism process and make a field ready to plan successful rural tourism based on strategy and operational way. Attention to compile the tourism development in the area show that ST, WO, SO and WT strategies have operational priority. To develop tourism in rural zone the order is as follows: first (ST) protecting from recreational attractions of the village; then, developing tourism infrastructure and introduce recreational attractions to attract tourism (WO); then tourism planning (SO) and finally tourism projecting will be the last rural tourism development strategies in the area.

\section{References}

Aarabi, S. M. (2006). Lecture note of strategic planning, cultural researches office press of Iran, 193pp.

Fred, R. D. (1999). Description of Strategic Management (Concepts and Cases), Prentice Hall press, 9th edition.

Kanaani, E. (2005). Tourism and impact on rural societies, Dahati journal, 70, 38-42.

Mostowfi, B. (2000). Agrotourism and sustainable development, case study: landscape design for Karyak village, MSc thesis, Environment Faculty of Tehran.170pp.

National statistical center of Iran. (1996). Public census of population and settlement.

National statistical center of Iran. (2006). Public census of population and settlement. 
Sharpley, R. R. (2001). Rural tourism and the challenge of tourism diversification: the case of Cyprus. Tourism Management, 23(3),233-244.

Yadghar, A. (2004). Changes process and challenges of rural reclamation and development in Iran, Journal of rural researches, 48, 71-90.

Table 1. Effective internal and external factors on rural development process in target village for tourism - Kore Shahbazi

\begin{tabular}{|c|c|c|c|c|}
\hline \multirow{2}{*}{ Factors } & \multicolumn{2}{|c|}{ Internal factors } & \multicolumn{2}{|c|}{ External factors } \\
\hline & Strength $(+)$ & Weakness (-) & Opportunity & Threat \\
\hline Bio-environmental & $\begin{array}{l}\text { 1) soil development and its fertility } \\
\text { 2) vast plain and mild topography } \\
\text { 3) non-native fruitful tree variations } \\
\text { 4) Taghar river }\end{array}$ & 1) weak flora in the area & $\begin{array}{l}\text { 1) developing agricultural and } \\
\text { gardening in the area } \\
\text { 2) area potential to be suitable with } \\
\text { non-native fruitful variations } \\
\text { 3)protection of wildlife habitat }\end{array}$ & 1) vast poverty of flora in the area \\
\hline Tourism & $\begin{array}{l}\text { 1) } 7 \text { months of comfort climate } \\
\text { 2) cheshme Belgheis garden } \\
\text { recreation place } \\
\text { 3) nice natural views } \\
\text { 4) historical attraction (Tal Baboune } \\
\text { historic castle) }\end{array}$ & $\begin{array}{l}\text { 1) lack of residential tourism } \\
\text { infrastructure } \\
\text { 2) few visitors of village } \\
\text { 3) the absence of tourism planning } \\
\text { in the village } \\
\text { 4) giving no information to introduce } \\
\text { the attraction }\end{array}$ & $\begin{array}{l}\text { 1) projection development } \\
\text { opportunity for Cheshme } \\
\text { Belgheis promenade } \\
\text { 2) planning opportunity for nature } \\
\text { tourism } \\
\text { 3) historical tourism planning } \\
\text { 4) being the target village for } \\
\text { tourism }\end{array}$ & $\begin{array}{l}\text { 1) being unaware of village's tourism } \\
\text { opportunity } \\
\text { 2) to gradually ruin of village } \\
\text { tourism attractions }\end{array}$ \\
\hline Economical & $\begin{array}{l}\text { 1) livelihood relying on agricultural } \\
\text { activities } \\
\text { 2) human resources for employment } \\
\text { 3) easy access to village }\end{array}$ & $\begin{array}{l}\text { 1) low prosperity of agricultural } \\
\text { activities } \\
\text { 2)lack of asphalt roads for access } \\
\text { 3) low employment opportunity } \\
\text { 4) low income }\end{array}$ & $\begin{array}{l}\text { 1) opportunity for more agricultural } \\
\text { activities } \\
\text { 2) opportunity for easy connection } \\
\text { to urban centers } \\
\text { 3) opportunity to exploit from } \\
\text { native workers }\end{array}$ & $\begin{array}{l}\text { 1) increasing unemployment } \\
\text { 2) difficulty in emergency relief }\end{array}$ \\
\hline Socio-cultural & $\begin{array}{l}\text { 1) native-cultural traditions stability } \\
\text { 2) family-tribal relations stability } \\
\text { 3) equipped health center }\end{array}$ & $\begin{array}{l}\text { 1)lack of educational services } \\
\text { 2) non-native architecture in } \\
\text { new-buildings }\end{array}$ & $\begin{array}{l}\text { 1) opportunity to mere preservation } \\
\text { from native-culture }\end{array}$ & $\begin{array}{l}\text { 1) immigration to adjacent cities and } \\
\text { villages } \\
\text { 2) decreasing the educational } \\
\text { opportunity in higher levels } \\
\text { 3) neglecting the native traditions for } \\
\text { rural architecture }\end{array}$ \\
\hline Legal-political & $\begin{array}{l}\text { 1) governmental ownership on } \\
\text { pasture lands } \\
\text { 2) governmental ownership on } \\
\text { tourism attractions } \\
\text { 3) Local council and in village }\end{array}$ & $\begin{array}{l}\text { 1) weakness to neglect the pasture } \\
\text { capacity to give the pasture license } \\
\text { 2) the absence of enough } \\
\text { supervision on natural resources } \\
\text { usage } \\
\text { 3) absence of native people in } \\
\text { decision-making process }\end{array}$ & $\begin{array}{l}\text { 1) governmental management on } \\
\text { recreation lands and resources } \\
\text { 2) cooperative management with } \\
\text { villagers }\end{array}$ & $\begin{array}{l}\text { 1) ruining the natural resources } \\
\text { 2) lack of sanction for government } \\
\text { programs by natives }\end{array}$ \\
\hline
\end{tabular}


Table 2. Effective internal and external factors on rural development process in target village for tourism: Tassouj

\begin{tabular}{|c|c|c|c|c|}
\hline \multirow{2}{*}{ Factors } & \multicolumn{2}{|c|}{ Internal factors } & \multicolumn{2}{|c|}{ External factors } \\
\hline & Strength $(+)$ & Weakness (-) & Opportunity & Threat \\
\hline Bio-environmental & $\begin{array}{l}\text { 1) high average for precipitation in } \\
\text { cold damp district } \\
\text { 2) settlement in dense forests of } \\
\text { Zagross } \\
\text { 3) various water resources } \\
\text { 4) various animal species }\end{array}$ & $\begin{array}{l}\text { 1) many frozen days } \\
\text { 2) high percentage of steep incline in } \\
\text { the area }\end{array}$ & $\begin{array}{l}\text { 1) evolution opportunity for pasture } \\
\text { lands } \\
\text { 2) support management of forests in } \\
\text { the area } \\
\text { 3) fruitful trees planting } \\
\text { 4) preservation of wild life }\end{array}$ & $\begin{array}{l}\text { 1) floral species to be frozen } \\
\text { 2) high soil erosion in steep incline } \\
\text { 3) destroying the forest } \\
\text { 4) absence of management to } \\
\text { optimum usage of water resources } \\
\text { 5) too much hunting in the area }\end{array}$ \\
\hline Tourism & $\begin{array}{l}\text { 1) } 5 \text { months of comfort climate } \\
\text { 2) natural promenade of Tassouj } \\
\text { waterfall } \\
\text { 3) historical attractions (stone tombs) } \\
\text { 4) religious attractions (Golbahar } \\
\text { Shrine) }\end{array}$ & $\begin{array}{l}\text { 1) lack of residential tourism } \\
\text { infrastructure } \\
\text { 2) few visitors of village } \\
\text { 3) absence of planning for tourism in } \\
\text { village } \\
\text { 4) lack of information to introduce } \\
\text { the attractions }\end{array}$ & $\begin{array}{l}\text { 1) potential for planning forest } \\
\text { recreation } \\
\text { 2) opportunity for planning waterfall } \\
\text { recreation place } \\
\text { 3) historical tourism planning } \\
\text { 4) religious tourism planning } \\
\text { 5) being the target village for tourism }\end{array}$ & $\begin{array}{l}\text { 1) neglecting the tourism opportunity in } \\
\text { village } \\
\text { 2) gradual ruin of tourism attraction in } \\
\text { village }\end{array}$ \\
\hline Economical & $\begin{array}{l}\text { 1) livelihood dependence on husbandry } \\
\text { 2) usage of non-wooden production of } \\
\text { forest } \\
\text { 3) human resources for employment }\end{array}$ & $\begin{array}{l}\text { 1) lack of agricultural activities } \\
\text { 2) absence of asphalt road } \\
\text { 3) low employment opportunity } \\
\text { 4) low income }\end{array}$ & $\begin{array}{l}\text { 1) the opportunity to get benefit from } \\
\text { husbandry activities } \\
\text { 2) setting up to use of non-wooden } \\
\text { forest productions } \\
\text { 3) opportunity for using native labor } \\
\text { work }\end{array}$ & $\begin{array}{l}\text { 1) increasing unemployment } \\
\text { 2) challenges to relieve in exigency } \\
\text { situations }\end{array}$ \\
\hline Socio-cultural & $\begin{array}{l}\text { 1) native - cultural tradition's stability } \\
\text { 2) family - tribal relation's stability }\end{array}$ & $\begin{array}{l}\text { 1) lack of sufficient educational } \\
\text { services } \\
\text { 2) lack of sufficient health services } \\
\text { 3) temporary village life } \\
\text { 4) non-native architecture in new } \\
\text { buildings }\end{array}$ & $\begin{array}{l}\text { 1) opportunity for preserving native } \\
\text { culture }\end{array}$ & $\begin{array}{l}\text { 1) immigration to adjacent villages and } \\
\text { cities } \\
\text { 2) decreasing the educational } \\
\text { opportunity in higher levels } \\
\text { 3) neglecting the native cultures for } \\
\text { rural architecture }\end{array}$ \\
\hline Legal-political & $\begin{array}{l}\text { 1) governmental ownership for pasture } \\
\text { and forest lands } \\
\text { 2) governmental ownership for } \\
\text { tourism attractions } \\
\text { 3) common limitations } \\
\text { 4) councils in village }\end{array}$ & $\begin{array}{l}\text { 1) weakness to neglect the pasture } \\
\text { capacity to give the pasture license } \\
\text { 2) absence of enough supervision on } \\
\text { natural resources usage } \\
\text { 3absence of native people in making } \\
\text { decision process decision making }\end{array}$ & $\begin{array}{l}\text { 1) government management for } \\
\text { recreation lands and resources } \\
\text { 2)cooperative management with } \\
\text { villages }\end{array}$ & $\begin{array}{l}\text { 1) ruining the natural resources } \\
\text { 2) the lack of sanction for government } \\
\text { programs by natives }\end{array}$ \\
\hline
\end{tabular}

Table 3. Strategies and ways for rural development in Kore Shahbazi Village

\begin{tabular}{|l|l|l|}
\hline \multicolumn{1}{|c|}{ Factors } & \multicolumn{1}{|c|}{ Strategy } & \multicolumn{1}{c|}{ Way } \\
\hline Bio-environmental & Improving flora & $\begin{array}{l}\text { 1) protect from runing the flora } \\
\text { 2) evolution pasture and forest lands in } \\
\text { talented area }\end{array}$ \\
\hline Economical & Improving employment capacity & $\begin{array}{l}\text { 1) create new employment opportunity } \\
\text { 2) optimize the process of current jobs }\end{array}$ \\
\hline Socio-cultural & Control the immigration rate & $\begin{array}{l}\text { 1) increase the welfare services capacity } \\
\text { 2) protect the culture genuine of villages }\end{array}$ \\
\hline Legal-political & $\begin{array}{l}\text { Partnership development in } \\
\text { planning }\end{array}$ & $\begin{array}{l}\text { make new opportunities for native people } \\
\text { giving the responsibilities to native people }\end{array}$ \\
\hline
\end{tabular}

Table 4. Strategies and ways for rural development in Tassouj village

\begin{tabular}{|l|l|l|}
\hline \multicolumn{1}{|c|}{ Factors } & \multicolumn{1}{|c|}{ Strategy } & \multicolumn{1}{c|}{ Way } \\
\hline Bio-environmental & $\begin{array}{l}\text { Bio-environment management for } \\
\text { natural resources }\end{array}$ & $\begin{array}{l}\text { 1) control the soil erosion } \\
\text { 2) manage the forest and water resources }\end{array}$ \\
\hline Economical & $\begin{array}{l}\text { Developing the infrastructure } \\
\text { (infrastructure development) }\end{array}$ & $\begin{array}{l}\text { 1) improve the accessibility roads to villages } \\
\text { 2) remove the infrastructure obstacle }\end{array}$ \\
\hline Socio-cultural & Control the immigration rate & $\begin{array}{l}\text { 1) increase the welfare services capacity } \\
\text { 2) preserve the culture genuine of a village }\end{array}$ \\
\hline Legal-political & $\begin{array}{l}\text { Partnership development in } \\
\text { planning }\end{array}$ & $\begin{array}{l}\text { 1) make new opportunities for the presence } \\
\text { of native partnership in decision making } \\
\text { 2) give the responsibilities to natives people }\end{array}$ \\
\hline
\end{tabular}


Table 5. SWOT matrix for Kore Shahbazi village

\begin{tabular}{|c|c|c|}
\hline \multirow[t]{2}{*}{ Internal factors } & Strength & Weakness \\
\hline & $\begin{array}{l}\text { 1) } 7 \text { month of comfort climate } \\
\text { 2) the garden of Cheshme } \\
\text { Belgheis recreation place } \\
\text { 3) beautiful natural views } \\
\text { 4) historical attractions (historic } \\
\text { castle) }\end{array}$ & $\begin{array}{l}\text { 1) absence of tourism } \\
\text { infrastructure } \\
\text { 2) few visitors of village } \\
\text { 3)absence of planning in village } \\
\text { 4) absence of information to } \\
\text { introduce the attractions }\end{array}$ \\
\hline Opportunity & SO Strategy & WO Strategy \\
\hline $\begin{array}{l}\text { 1) planning development for } \\
\text { Belgheis promenade } \\
\text { 2) planning for natural tourism } \\
\text { 3) planning for historical tourism } \\
\text { 4) being the target village for } \\
\text { tourism }\end{array}$ & $\begin{array}{l}\text { 1) plan to expand the nature } \\
\text { tourism } \\
\text { 2) plan to expand the } \\
\text { historical-religious tourism }\end{array}$ & $\begin{array}{l}\text { 1) infrastructure development for } \\
\text { nature, historic and religious } \\
\text { tourism } \\
\text { 2) introduce recreational } \\
\text { attractions of village to attract } \\
\text { tourists }\end{array}$ \\
\hline Threats & ST Strategy & WT Strategy \\
\hline $\begin{array}{l}\text { 1) neglect to use of tourism } \\
\text { opportunity in village } \\
\text { 2) gradual ruin of tourism } \\
\text { attractions in village }\end{array}$ & $\begin{array}{l}\text { 1) preserving recreational } \\
\text { attraction of village }\end{array}$ & $\begin{array}{l}\text { 1) tourism planning based on } \\
\text { recreational attractions }\end{array}$ \\
\hline
\end{tabular}

Table 6. SWOT matrix for Tassouj village

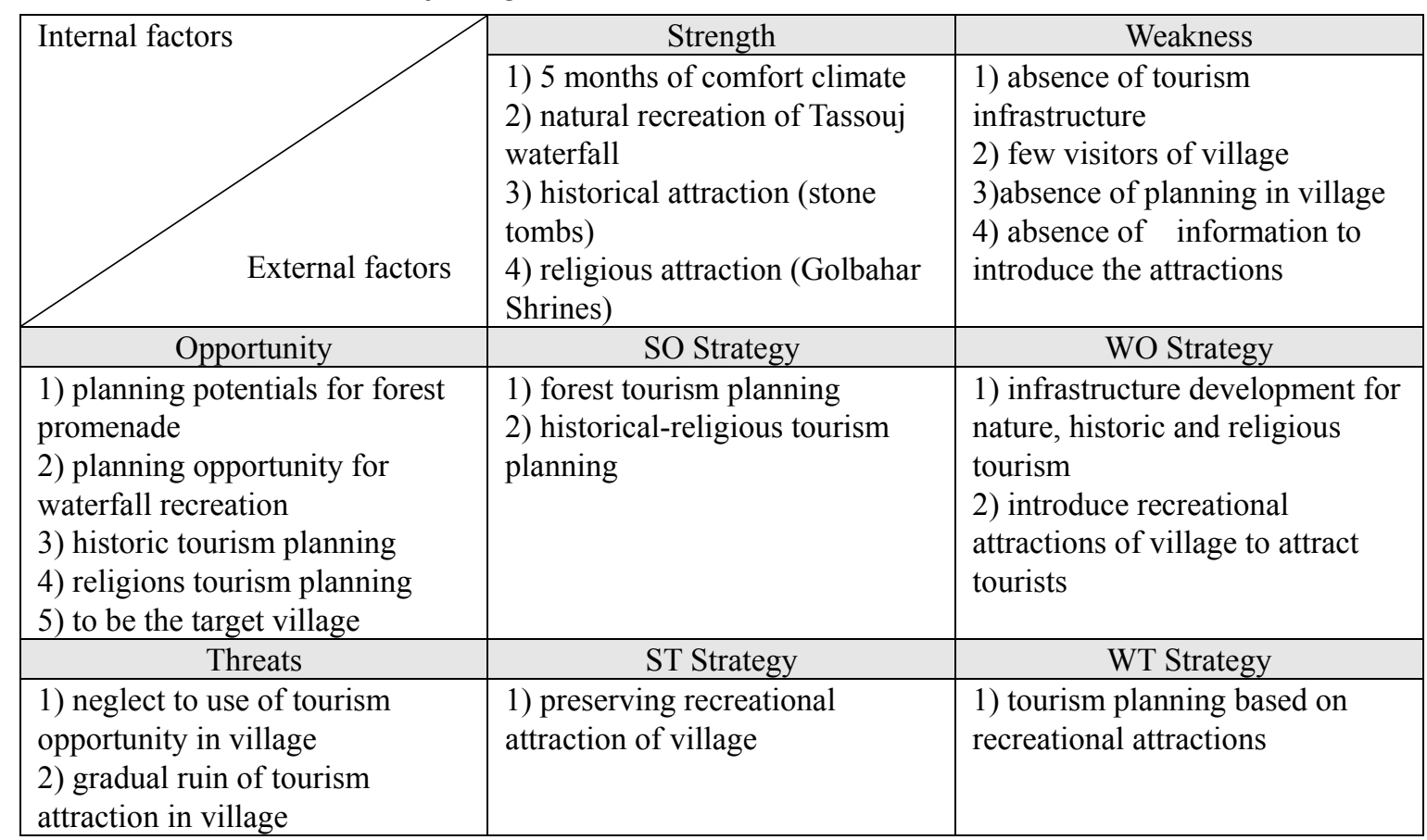

